\title{
ACCURACY ASSESSMENT OF GPS PRECISE POINT POSITIONING (PPP) TECHNIQUE USING DIFFERENT WEB-BASED ONLINE SERVICES IN A FOREST ENVIRONMENT
}

\author{
PROCJENA TOČNOSTI TEHNIKE PRECIZNOG ODREĐIVANJA \\ POLOŽAJA TOČKE GPS-OM KORIŠTENJEM INTERNETSKIH \\ USLUGA U ŠUMSKOM OKRUŽENJU
}

\author{
Taylan OCALAN
}

\section{Summary}

Since Global Positioning System (GPS) has been routinely conducted in many engineering projects, it is also effectively applied to the assessment and preventing of forest and natural resources. Depending on the GPS survey method preferred in the applications performed around the forest environments, different level point positioning accuracy can be achieved. Traditionally, for many precise positioning applications, relative static positioning has been used. The data obtained have been analyzed with high-cost scientific and commercial software, which are required a good knowledge of processing procedures. However, in recent years, web based online services that use Precise Point Positioning (PPP) technique, developed as a special type of relative positioning, that enables to process and analyze the static data easily, have become a significant alternative for users. These developments on GPS based surveyings that significantly make contributions to the studies applied around the forest environment, in terms of time, cost, accuracy and labour are preferred in many engineering facilities. In this study, it is aimed to research performance of GPS PPP technique and web based online services in positioning applications especially performed around the forest environments. For this purpose, two test stations have been established in different locations around the forest area, located in Campus of Davutpasa, Yildiz Technical University, Istanbul, and stations have been observed repeatedly in static GPS surveying mode for 3 days and per day with 3-hours observation duration. The observations have been computed by commercial software as using final GPS ephemerides products so called TopconTools v8.2 and also by web based online services namely OPUS, AUSPOS, CSRS-PPP, GAPS and APPS.

From the results, when $3 \mathrm{D}$ positioning differences have been examined, it is seen that the positional accuracy is range from $0.024 \mathrm{~m}$ to $0.251 \mathrm{~m}$ for TP01 and from $0.078 \mathrm{~m}$ to $1.033 \mathrm{~m}$ for TP02 with respect to both relative solution and PPP solution, which is used by web based online services. When the results have been examined for only CSRS-PPP, APPS and GAPS services, which are used PPP solution, it is seen that the positional accuracy for $3 \mathrm{D}$ positioning differences is range from $0.024 \mathrm{~m}$ to $0.251 \mathrm{~m}$ for TP01 and from $0.078 \mathrm{~m}$ to $0.859 \mathrm{~m}$ for TP02.

The results show that since the static GPS data is collected for duration of 3-hours and more, PPP technique and the web based online services using this technique for precise positioning applications around the forest environment give effective solutions to the users and at the same time decrease the survey cost with respect to equipment and software.

KEY WORDS: GPS, PPP, web-based online services, forest environments, positioning accuracy 


\section{INTRODUCTION AND RESEARCH PROBLEMS UVOD I PROBLEMI ISTRAZZIVANJA}

Global Navigation Satellite Systems (GNSS), which consists of satellite technologies such as GPS (USA), GLONASS (Russia), BeiDou (China) and Galileo (EU), is the positioning and navigation system based on artificial satellites. Among them, GPS has been effectively implemented in positioning, navigation and timing applications over the last three decades. With this aspect, GPS serves several facilities such as assesment and preventing the forest and natural resources, environmental and urban planning, land use and agricultural policy, monitoring the global climate change, engineering and infrastructure services, engineering and utilization applications, e-government and personal mobile applications to the services. Moreover high precise positioning information is indispensible for various services in forestry discipline such as protection and efficient utilization of forests, forest road planning, destruction of forests, protection against or putting out of fires, inventories, insect infestation and boundary determination. In addition to this, in geomatic engineering applications, the system has been used for establishing the geodetic networks, cadastre surveys, monitoring the deformations, geographic information system (GIS), photogrammetry and Light Detection and Ranging (LIDAR) applications, where decimeter, centimeter and milimeter level accuracies are required to point positioning (Pirti, 2005; Pirti, 2008; Ocalan and Tunalioglu, 2010; Awange, 2012; Ocalan et al. 2013; Pirti et al.,2015).

Traditionally, most of the professional GPS users have used relative (differential) positioning technique to provide high accuracy. However, this technique has some limitations. Minimum two or more GPS receivers should be used and the true coordinates of the reference stations should be known. Addition to this, increase of the distance between reference station (base) and rover station has reduced the position accuracy (El-Rabbany, 2006; Hoffmann-Wellenhof et al., 2008; Abd-Elazeem et al., 2011). Simultaneous observations should be made with at least two GNSS receivers: one should be occupied a reference station whose coordinates are known, and the other should be established to the point whose coordinates will be estimated. Several criteria such as; preferred survey mode (static or kinematic), observation time, the equipment used, signals and codes, data processing algorithms, infrastructure of the reference receiver/s, satellite-receiver geometry, post-processing evaluation or real time applications, provide different level accuracies for positioning. For instance, while in differential GNSS (DGNSS) technique where single-frequency code (pseudorange) observations are used, decimeter level positioning accuracy can be achieved, in real time kinematic (RTK) techniques where dual/multi-frequency carrier phase observations are used, centimeter level positioning accuracy can be derived (Rizos vd., 2012). To obtain more accurate positioning, GPS observations should be collected in relative static surveying mode, and then computed with different post-processing scientific or commercial software.

However, in recent years, a method, namely PPP, has become an alternative technique to relative and differential techniques to provide high precision positioning. GPS PPP technique, which is a developed type of absolute positioning, has been implemented effectively by users. This developing process has also affected the GPS data processing and analyzing software, which provides user-friendly and free web based online positioning services developed by several organizations. These services have been used commonly by GPS users in recent years, which are significantly alternatives to the high-cost scientific and commercial software. Figure 1 represents the basic working principle of these systems, which may serve either relative positioning or PPP technique. However, the number of web based online services has been increased in recent years (Tsakiri, 2008; Alkan and Ocalan, 2013; Ocalan, 2015).

As seen in Figure 1, users upload their data to the web pages of these services via internet. The results evaluated and analyzed by engine processes send back to the users via e-mail, which contains coordinates of estimated point (X, Y,Z), standard deviations (SD), root mean squares (RMS) error. Some services also send a comprehensive analyze report, which involves GPS error components and graphics beside them mentioned above. These services use high accurate data and products provided by International GNSS Service (IGS). IGS, which makes contributions for comprising and developing

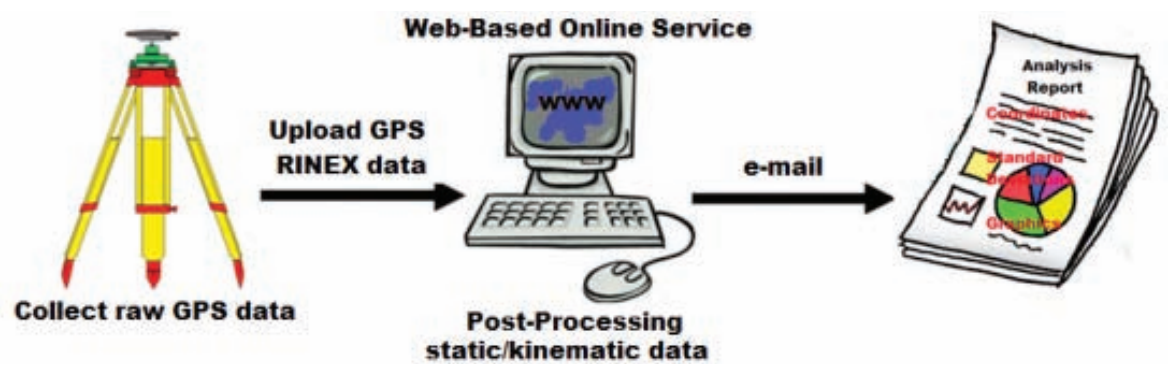

Figure 1: The basic working principle of web-based online services

Slika 1: Osnovni princip rada internetskih usluga 
the GNSS standards all around the world, has an important mission to archiving and presenting the information such as GPS/GLONASS satellite ephemerides data, earth rotation parameters, coordinates and velocity data of IGS stations, clock data of GPS/GLONASS satellites and IGS stations, ionospheric and tropospheric data. Moreover, not only IGS but also several organizations such as Jet Propulsion Laboratory (JPL), Natural Resources Canada (NRCan), Center for Orbit Determination in Europe (CODE) and Bundesamt für Kartographie und Geodäsie (BKG) have a significant role in terms of data providing for GPS/GNSS positioning.

The raw data collected from anywhere in the world with only one dual frequency geodetic grade GPS receiver may be converted to the Receiver Independent EXchange (RINEX) format, and may be uploaded to one of these services to process. However, there are some specific factors such as data processing solution techniques, solution algorithms (mathematical model), products used and accuracies of them (reference station coordinates, satellite ephemerides and clock corrections, atmospheric parameters etc.) and observation duration to estimate high accurate point positions. These services aid to the users in traditional GPS survey and processing studies with several advantages in terms of software, hardware, equipment, personnel and logistics costs.

Table 1 shows the specifications and classifications of these services, of which give especially effective solutions for static GPS observation data with long observation durations (2 hours and over). The services listed, which have different technical specifications, have been commonly used by several disciplines for precise positioning. These services when compared with the commercial and scientific software, that are not required long term training and easy use, have made the use of PPP technique common. Since these services have some differences with respect to service features such as membership requirement, storage limitation of the GPS/ GNSS RINEX data to be uploaded, process in static/kine- matic modes, evaluation the data collected by single/dual or multi frequency receiver, GPS/GNSS antenna type selection, users are interested in them (URL-2; URL-3; URL-4; URL5; URL-6; URL-7; URL-8).

\section{PURPOSE OF RESEARCH SVRHA ISTRAŽIVANJA}

The aim of the study is to investigate the positioning accuracy of the PPP method and also to expose the accuracy assessment of PPP technique by using different web based online services under the forest environment. Moreover, the study investigates decrease the survey budget and equipment in terms of using web based online services and single GPS receiver to provide high accurate point positions. For this purpose, two station points, which one of them is in the forest area and the other is close to the forest environment, have been established around the forest environment, and then long-term and repeated static GPS observations have been collected. The data collected have been processed by commercial software (Topcon Tools v8.2) and web-based online services (OPUS, AUSPOS, CSRS-PPP, GAPS, APPS) to research especially accuracy of the GPS PPP technique. Since there are some restrictions for use of GPS in the forest environment, it is effectively used for surveying applications by different disciplines. Thus, performance of GPS PPP technique is investigated especially in forest environment for point-positioning applications using web based online services.

\section{DEFINITION OF THE STUDY AREA DEFINICIJA PODRUČJA ISTRAŽIVANJA}

The study area is located around the forest environment in Campus of Davutpasa, Yildiz Technical University, Istanbul. The selected area is in the urban forest and the topography of the surface has a flat terrain feature. The canopy of the

Table 1: Post-process web-based online services using relative and PPP technique solutions

Tablica 1: Postprocesne internetske usluge koje koriste relativna i PPP tehnička rješenja

\begin{tabular}{|c|c|c|c|c|c|c|}
\hline $\begin{array}{l}\text { Solution } \\
\text { Technique / } \\
\text { Tehnika rješenja }\end{array}$ & $\begin{array}{l}\text { Service Short } \\
\text { Name / Skraćeni } \\
\text { naziv usluge }\end{array}$ & $\begin{array}{c}\text { Organization/Company / } \\
\text { Organizacija/Tvrtka }\end{array}$ & $\begin{array}{c}\text { Data Type } \\
\text { / Vrsta } \\
\text { podataka }\end{array}$ & $\begin{array}{l}\text { Post-Processing Mode / } \\
\text { Postprocesni način }\end{array}$ & $\begin{array}{l}\text { Software / } \\
\text { Softver }\end{array}$ & $\begin{array}{c}\text { Coordinates } \\
\text { (Datum)/ } \\
\text { Koordinate (Datum) }\end{array}$ \\
\hline \multirow{2}{*}{$\begin{array}{l}\text { Relative / } \\
\text { Relativna }\end{array}$} & AUSPOS & Geoscience Australia & GPS & Static / Statični & Bernese & ITRF2008 \\
\hline & OPUS & USA National Geodetic Survey & GPS & $\begin{array}{l}\text { Static/Rapid Static/ } \\
\text { Statični/Brzi statični }\end{array}$ & PAGES & ITRF2008 \\
\hline \multirow{5}{*}{ PPP } & CSRS-PPP & Natural Resources Canada & GNSS & $\begin{array}{l}\text { Static/Kinematic / } \\
\text { Statični/Kinematički }\end{array}$ & NRCanPPP & ITRF2008 \\
\hline & GAPS & University of New Brunswick & GPS & $\begin{array}{l}\text { Static/Kinematic / } \\
\text { Statični/Kinematički }\end{array}$ & GAPS & ITRF2008 \\
\hline & APPS & NASA Jet Propulsion Laboratory & GPS & $\begin{array}{l}\text { Static/Kinematic / } \\
\text { Statični/Kinematički }\end{array}$ & Gipsy & ITRF2008 \\
\hline & magic-GNSS & GMV Innovating Solutions & GNSS & $\begin{array}{l}\text { Static/Kinematic / } \\
\text { Statični/Kinematički }\end{array}$ & $\begin{array}{l}\text { magic } \\
\text { PPP }\end{array}$ & ITRF2008 \\
\hline & Trimble RTX & Trimble Navigation Limited & GNSS & Static / Statični & Trimble & ITRF2008 \\
\hline
\end{tabular}




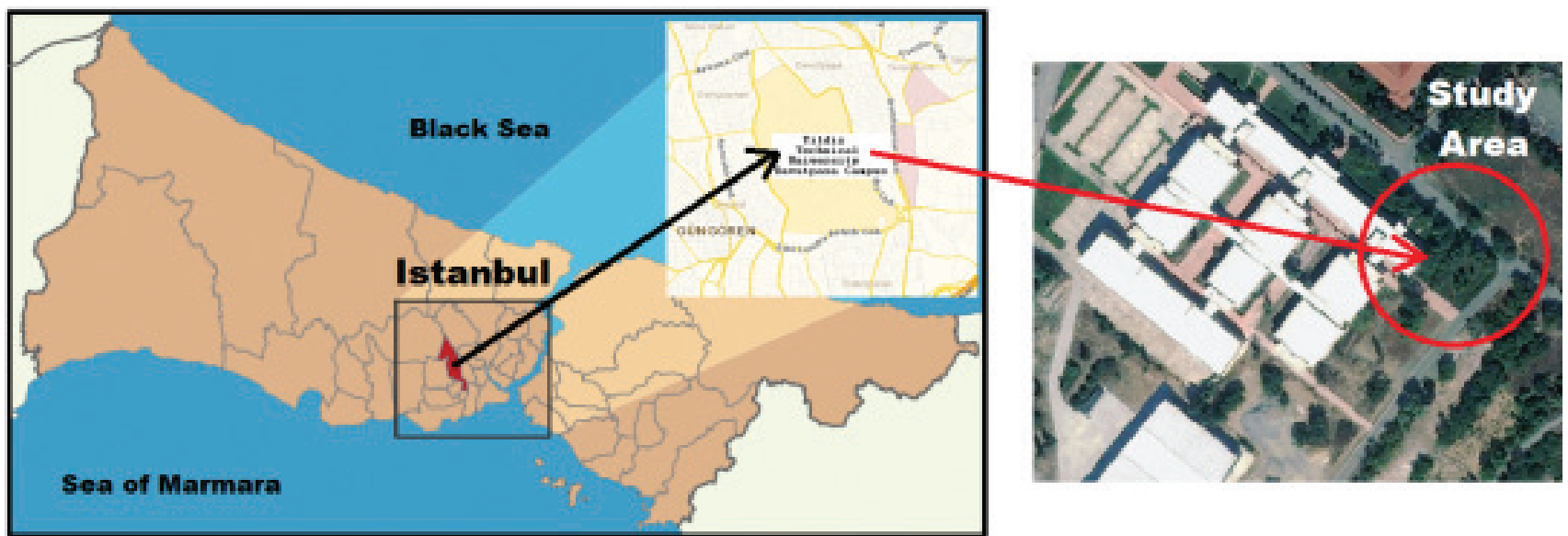

Figure 2: Study area

Slika 2: Područje istraživanja

forest area, where the study has been performed, is coniferous. This brings an advantage with respect to transmission of the GPS signals to the receiver antenna. This is a signifi-

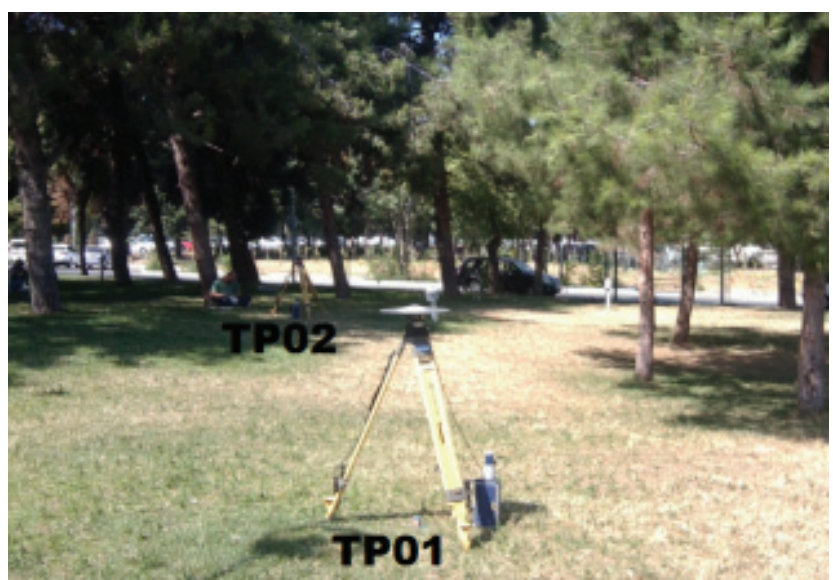

Figure 3a: View of TP01 and TP02 at the field site Slika 3a: Pogled na TP01 i TP02 na licu mjesta cant feature for GPS surveying where conducted around the forest environment. Because, the characteristic features of the tree species may affect the accuracy of the point positioning with respect to sky visibility, cycle slip and multipath. For this experimental study, two test stations, which one (TP01) is near the border of forest area and the other (TP02) is in the forest area, have been established as seen in Figure 2. The detailed description of the location of points established may be seen in Figure 3a and 3b.

\section{MATERIALS AND METHODS MATERIJALI I METODE}

Precise Point Positioning (PPP) Technique - Tehnika preciznog određivanja položaja (PPP)

The first research that shows the relationship between PPP technique and GPS has been stated by Zumberge et al. (1997). In Zumberge et al. (1997), PPP has been modelled by ionosphere-free combinations using both pseudorange

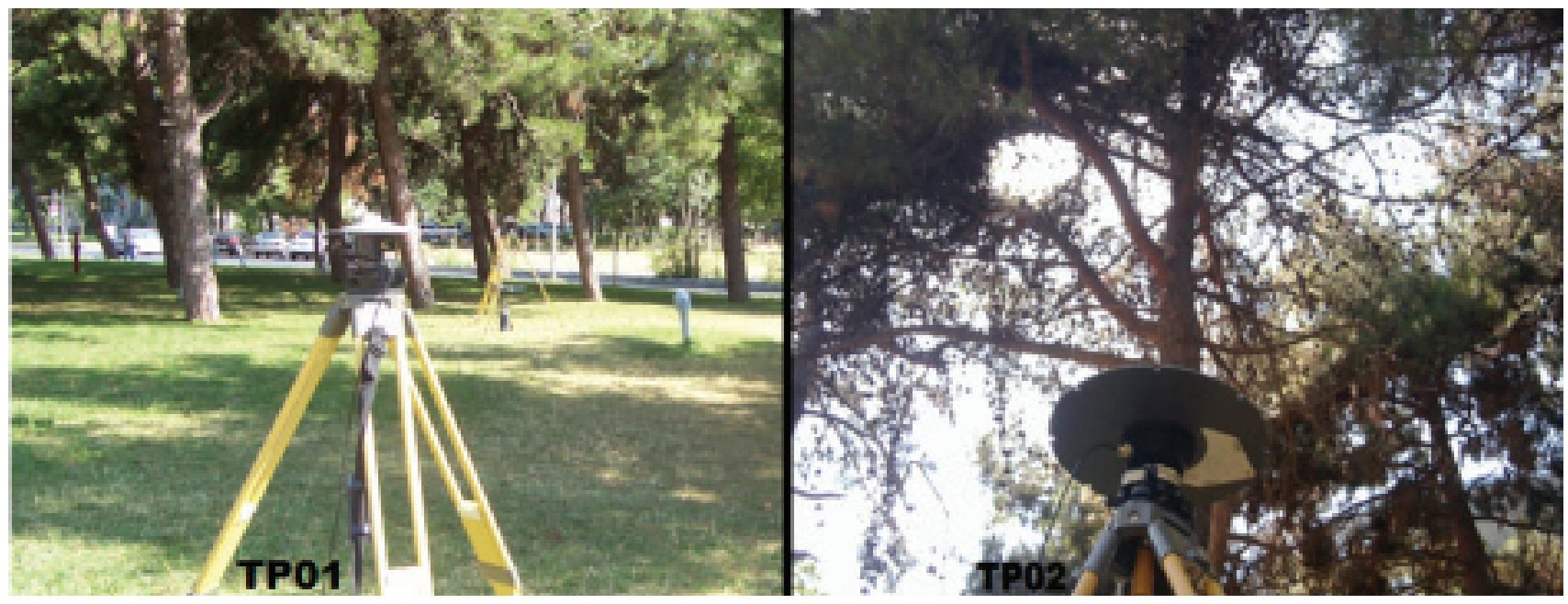

Figure 3b: The close view of TP01 and TP02 at the field site

Slika 3b: Pogled izbliza na TP01 i TP02 na licu mjesta 
Table 2: IGS GPS satellite ephemerides / satellite \& station clocks (URL-1)

Tablica 2: IGS GPS satelitske astronomske tablice/ satelitski sat i sat stanice (URL-1)

\begin{tabular}{|c|c|c|c|c|}
\hline \multicolumn{2}{|c|}{ Products Type / Vrsta proizvoda } & Accuracy & Latency & Sample Interval \\
\hline \multirow[b]{2}{*}{ Broadcast / Prijenos } & Orbits / Orbita & $\sim 100 \mathrm{~cm}$ & & \\
\hline & Satellite Clocks / Satelitski sat & $\begin{array}{c}\sim 5 \mathrm{~cm} \mathrm{RMS} \\
\sim 2.5 \mathrm{~ns} \text { St.Dev. }\end{array}$ & $\begin{array}{c}\text { Real-Iıme / } \\
\text { Realno vrijeme }\end{array}$ & Daily / Dnevno \\
\hline $\begin{array}{l}\text { Ultra-Rapid (predicted half) / } \\
\text { Ultrabrzo (predviđena polovica) }\end{array}$ & $\begin{array}{c}\text { Orbits / Orbita } \\
\text { Satellite Clocks / Satelitski sat }\end{array}$ & $\begin{aligned} & \sim 5 \mathrm{~cm} \\
\sim & 3 \mathrm{~ns} \text { RMS } \\
\sim & 1.5 \mathrm{~ns} \text { St.Dev. }\end{aligned}$ & $\begin{array}{c}\text { Real-Time / } \\
\text { Realno vrijeme }\end{array}$ & 15 minutes / 15 minuta \\
\hline $\begin{array}{l}\text { Ultra-Rapid (observed half) / } \\
\text { Ultrabrzo (promatrana polovica) }\end{array}$ & $\begin{array}{c}\text { Orbits / Orbita } \\
\text { Satellite Clocks / Satelitski sat }\end{array}$ & $\begin{aligned} & \sim 3 \mathrm{~cm} \\
\sim & 150 \text { ps RMS } \\
\sim & 50 \text { ps St.Dev. }\end{aligned}$ & $\begin{array}{c}3-9 \text { hours / } \\
3-9 \text { sati }\end{array}$ & 15 minutes / 15 minuta \\
\hline \multirow[b]{2}{*}{ Rapid / Brzo } & Orbits / Orbita & $\sim 2.5 \mathrm{~cm}$ & \multirow[b]{2}{*}{$\begin{array}{l}17-41 \text { hours / } \\
17-41 \text { sati }\end{array}$} & 15 minutes / 15 minuta \\
\hline & $\begin{array}{c}\text { Sat.\&Stn. Clocks / } \\
\text { Satelitski sat i sat stanice }\end{array}$ & $\begin{array}{c}\sim 75 \text { ps RMS } \\
\sim 25 \text { ps St.Dev. }\end{array}$ & & 5 minutes / 5 minuta \\
\hline \multirow[b]{2}{*}{ Final / Konačno } & Orbits / Orbita & $\sim 2.5 \mathrm{~cm}$ & \multirow[b]{2}{*}{$\begin{array}{l}12-18 \text { days / } \\
12-18 \text { dana }\end{array}$} & 15 minutes / 15 minuta \\
\hline & $\begin{array}{l}\text { Sat.\&Stn. Clocks / } \\
\text { Satelitski sat i sat stanice }\end{array}$ & $\begin{array}{l}\sim 75 \text { ps RMS } \\
\sim 20 \text { ps St.Dev. }\end{array}$ & & $\begin{array}{c}\text { Sat.: } 30 \text { seconds } \\
\text { Stn.: } 15 \text { minutes / Sat.: } 30 \text { sekunda } \\
\text { Stn.: } 15 \text { minuta }\end{array}$ \\
\hline
\end{tabular}

and carrier phase observations. After this study that presents the mathematical model of PPP technique, Kouba and Héroux (2001) gives the acceleration on PPP. In PPP method, the satellite ephemerides data and the clock estimations have been provided by permanent GPS/GNSS reference stations network. In this point, the most important source of accurate orbital and satellite clock data is IGS. Table 2 represents the comprehensive information about the accurate GPS satellite ephemerides and the accurate clock data provided by IGS. According to the developments on satellite geodesy, precise orbit and clock products are obtained by organizations such as IGS, JPL etc., and these are presented to the users.

Due to these developments, PPP technique becomes the most effective and novel method on GPS positioning. PPP is an absolute positioning technique, which provides $\mathrm{cm}$ or $\mathrm{dm}$ level point accuracy in static or kinematic mode depending on observation duration with a dual- frequency receiver. PPP uses undifferenced ionospheric-free both carrierphase $(\Phi)$ and code pseudorange $(P)$ observations collected by dual-frequency receiver for data processing. This technique provides precise positioning by using precise ephemeris and clock products provided by IGS and other organizations and by considering other corrections such as satellite effects (satellite antenna offsets and phase wind-up), site displacement effect (solid earth tides, polar tides, ocean loading, earth rotation parameters) and compatibility considerations (products formats, reference frames, receiver antenna phase center offsets, modeling/observation conventions) (Gao and Shen, 2002; Rizos et al., 2012; Kouba and Héroux, 2001; Gao and Shen, 2001; Zumberge, 1997).

As stated in both Zumbarge et al. (1997) and Kouba and Heroux (2001), the ionospheric-free combinations of dualfrequency GPS pseudorange $(P)$ and carrier-phase observations $(\Phi)$ are related to the user position, clock, troposp- here and ambiguity parameters according to the following simplified observation equations:

$$
\begin{gathered}
P=\rho+C(d T-d t)+T_{r}+\varepsilon_{P} \\
\Phi=\rho+C(d T-d t)+T_{r}+N \lambda+\varepsilon_{\Phi}
\end{gathered}
$$

where;

$P$ is the ionosphere-free combination of $P 1$ and $P 2$ pseudoranges $(P 3)=(2.546 P 1-1.546 P 2)$

$\Phi$ is the ionosphere-free combination of L1 and L2 carrierphases $(L 3)=\left(2.546 \lambda_{1} \Phi_{1}-1.546 \lambda_{2} \Phi_{2}\right)$

$\rho$ is the geometrical range computed as a function of satellite and station coordinates

$C$ is the vacuum speed of light

$d T$ is the station receiver clock offset from the GPS time $d t$ is the satellite clock offset from the GPS time

$T_{r}$ is the signal path delay due to the neutral-atmosphere (primarily the troposphere)

$N$ is the non-integer ambiguity of the carrier-phase ionosphere-free combination

$\lambda_{1}, \lambda_{2}, \lambda$ are the of the carrier-phases $L 1, L 2$ and L3-combined $(10.7 \mathrm{~cm})$ wavelengths, respectively

$\varepsilon_{\mathrm{P}}, \varepsilon_{\Phi}$ are the relevant measurement noise components, including multipath.

Despite the advantages of PPP technique, the most problematic issue is requirement of long convergence time for solving the carrier phase integer ambiguity. It is the long convergence times (of the order of 20 minutes or more) necessary for the ambiguity float solution to converge so as to ensure centimeter-level positioning accuracy (Rizos et al., 2012). Thus, increasing the observation duration is the significant factor for improving the accuracy of point positioning esti- 
Table 3: Biases and errors for PPP and relative/differential GNSS positioning techniques (Rizos et al., 2012).

Tablica 3: Pristranosti i greške za PPP i relativne/diferencijalne GNSS tehnike određivanja položaja

\begin{tabular}{|c|c|c|}
\hline $\begin{array}{c}\text { Correction Type / Tip korekcije } \\
\text { Satellite Specific Errors / Greške specifične za satelit }\end{array}$ & PPP & $\begin{array}{l}\text { Relative/Differential } \\
\text { GNSS }\end{array}$ \\
\hline Precise Satellite Clock Corrections / Precizne korekcije satelitskog sata & $\checkmark$ & $x$ \\
\hline Satellite Antenna Phase Centre Offset / Pomak faznog centra satelitske antene & $\checkmark$ & $\checkmark$ \\
\hline Satellite Antenna Phase Centre Variations / Varijacija faznog centra satelitske antene & $\checkmark$ & $\checkmark$ \\
\hline Precise Satellite Orbits / Precizne satelitske orbite & $\checkmark$ & $\checkmark / x$ \\
\hline Group Delay Differential / Diferencijal grupne odgode & $\checkmark($ L1 only) / (samo L1) & $x$ \\
\hline Relativity Term / Uvjet relativnosti & $\checkmark$ & $x$ \\
\hline $\begin{array}{l}\text { Satellite Antenna Phase Wind-Up Error / Efekt namatanja faznog centra satelitske antene } \\
\qquad \text { Receiver Specific Errors / Greške specifične za prijamnik }\end{array}$ & $\checkmark$ & $x$ \\
\hline Receiver Antenna Phase Centre Offset / Pomak faznog centra antene prijamnika & $\checkmark$ & $\checkmark$ \\
\hline Receiver Antenna Phase Centre Variations / Varijacija faznog centra antene prijamnika & $\checkmark$ & $\checkmark$ \\
\hline $\begin{array}{l}\text { Receiver Antenna Phase Wind-Up / Efekt namatanja faznog centra antene prijamnika } \\
\text { Geophysical Models / Geofizikalni modeli }\end{array}$ & $\checkmark$ & $x$ \\
\hline Solid Earth Tide Displacements / Pomicanje kopna & $\checkmark$ & $x$ \\
\hline Ocean Loading / Promjene oceana & $\checkmark$ & $x$ \\
\hline Polar Tides / Polarna plima & $\checkmark$ & $x$ \\
\hline $\begin{array}{l}\text { Plate Tectonic Motion / Kretanje tektonskih ploča } \\
\text { Atmospheric Modelling / Atmosfersko modeliranje }\end{array}$ & $\checkmark$ & $x$ \\
\hline Tropospheric Delay / Troposfersko kašnjenje & $\checkmark$ & $\checkmark$ \\
\hline Ionospheric Delay / lonosfersko kašnjenje & $\checkmark($ L1 only) / (samo L1) & $x$ \\
\hline
\end{tabular}

mated by PPP. The accuracy of satellite ephemerides data and clock products used in the technique, and error models considered in the computations refer strongly to the point positions to be estimated. Considering seperately the error models shown in Table 3 are especially significant factors for improving the accuracy of point positioning in PPP.

\section{Static GPS Surveying and Data Analysis - Statično ispitivanje GPS-om i analiza podataka}

In this study, the established ground control points so called TP01 and TP02 have been observed repeatedly in static GPS surveying mode for 3 days and per day with 3-hours observation duration. Surveys have been conducted on consecutive days at $16^{\text {th }}, 17^{\text {th }}, 18^{\text {th }}$ July 2012 (GPS Day of year=Doy: 198-199-200). During the surveys, dual frequency Thaless Z-max geodetic grade GPS receivers and Ashtech (ASH701008.01B NONE) geodetic grade antennas have been used. For all surveys, the record interval is 1 second and satellite cut-off angle is taken 10 degree. The heights of GPS antennas were measured in millimeter accuracy. The software and services listed in Table 4 have been used for post-processing and analyzing the static GPS data observed. The commercial software Topcon Tools v8.2 have been preferred to manually process of the data. The automatic processing has been done by web based online services namely AUSPOS, OPUS, CSRS-PPP, APPS and GAPS. The results have been provided in observation epoch and International Terrestrial Reference Frame 2008 (ITRF2008) datum. Final satellite ephemerides products provided by IGS have been used for both manual and automatic processing except
APPS service. APPS service uses final satellite ephemerides products provided by JPL.

PALA and KCEK permanent stations included in İSKİCORS network operated in Istanbul have been taken as reference stations for the solutions with commercial software Topcon Tools v8.2. The PALA and KCEK stations are approximately $10 \mathrm{~km}$ far away from the study area. In the evaluation process, IGS final ephemerides products have been considered (URL-9).

\section{RESULTS AND DISCUSSION} REZULTATI I RASPRAVA

From the analyzes that have been obtained from processing the static GPS data observed around the forest environment, with different software, the cartesian coordinates and standard deviations of them obtained for two test stations are represented in Table 5 and Table 6.

Table 4: Data post-processing mode for software and services used Tablica 4: Podaci postprocesnog načina za korišteni softver i usluge

\begin{tabular}{ccc} 
Type / Tip & $\begin{array}{c}\text { Softwares \& Services / } \\
\text { Softver i usluge }\end{array}$ & $\begin{array}{c}\text { Post-Processing Mode / } \\
\text { Postprocesni način }\end{array}$ \\
\hline $\begin{array}{c}\text { Commercial Software / } \\
\text { Komercijalni softver }\end{array}$ & $\begin{array}{c}\text { TopconTools v8.2 } \\
\end{array}$ & \\
& AUSPOS & Relative / Relativni \\
Web-Besed & OPUS & \\
Online Services / & CSRS-PPP & \\
Internetske usluge & APPS & PPP \\
& GAPS & \\
&
\end{tabular}


Table 5: Coordinates and standard deviations of TP01 (Doy:198-199-200)

Tablica 5: Koordinate i standardne devijacije za TP01 (Doy:198-199-200)

\begin{tabular}{rcccccc}
\hline TP01 - Doy:198 & $X(\mathrm{~m})$ & $Y(\mathrm{~m})$ & $Z(\mathrm{~m})$ & $S_{X}(\mathrm{~m})$ & $S_{Y}(\mathrm{~m})$ & $S_{Z}(\mathrm{~m})$ \\
\hline TopconTools v8.2 & 4219291.3010 & 2328143.7380 & 4164435.8270 & 0.0043 & 0.0035 & 0.0090 \\
AUSPOS & 4219291.3420 & 2328143.7750 & 4164435.8640 & 0.0140 & 0.0120 & 0.0610 \\
OPUS & 4219291.3740 & 2328143.7840 & 4164435.8510 & 0.0160 & 0.0390 & 0.0040 \\
CSRS-PPP & 4219291.4290 & 2328143.8550 & 4164435.9560 & 0.0190 & 0.0060 & 0.0100 \\
APPS & 4219291.3294 & 2328143.7592 & 4164435.8548 & 0.0130 & 0.0068 & 0.0099 \\
GAPS & 4219291.3583 & 2328143.7865 & 4164435.8780 & 0.0037 & 0.0012 & 0.0019 \\
\hline TP01 - Doy:199 & $X(\mathrm{~m})$ & $Y(\mathrm{~m})$ & $Z(\mathrm{~m})$ & $S_{X}(\mathrm{~m})$ & $S_{Y}(\mathrm{~m})$ & $S_{Z}(\mathrm{~m})$ \\
\hline TopconTools v8.2 & 4219291.3090 & 2328143.7610 & 4164435.8280 & 0.0047 & 0.0036 & 0.0100 \\
AUSPOS & 4219291.2380 & 2328143.8290 & 4164435.8490 & 0.0180 & 0.0140 & 0.0490 \\
OPUS & 4219291.3310 & 2328143.8570 & 4164435.9040 & 0.0220 & 0.1410 & 0.0570 \\
CSRS-PPP & 4219291.4360 & 2328143.8690 & 4164435.9670 & 0.0110 & 0.0160 & 0.0110 \\
APPS & 4219291.2899 & 2328143.7522 & 4164435.8174 & 0.0093 & 0.0065 & 0.0080 \\
GAPS & 4219291.3144 & 2328143.7921 & 4164435.8769 & 0.0016 & 0.0020 & 0.0017 \\
TP01 - Doy:200 & $X(\mathrm{~m})$ & $Y(\mathrm{~m})$ & & $S_{X}(\mathrm{~m})$ & $S_{Y}(\mathrm{~m})$ & $S_{Z}(\mathrm{~m})$ \\
\hline TopconTools v8.2 & 4219291.3050 & 2328143.7540 & 4164435.8310 & 0.0043 & 0.0035 & 0.0090 \\
AUSPOS & 4219291.2760 & 2328143.7400 & 4164435.8280 & 0.0110 & 0.0080 & 0.0350 \\
OPUS & 4219291.2940 & 2328143.7590 & 4164435.8520 & 0.0340 & 0.0490 & 0.0250 \\
CSRS-PPP & 4219291.4660 & 2328143.8380 & 4164436.0040 & 0.0090 & 0.0120 & 0.0090 \\
APPS & 4219291.2655 & 2328143.7265 & 4164435.8052 & 0.0073 & 0.0053 & 0.0062 \\
GAPS & 4219291.3075 & 2328143.7296 & 4164435.8594 & 0.0013 & 0.0017 & 0.0014
\end{tabular}

Table 6: Coordinates and standard deviations of TP02 (Doy:198-199-200)

Tablica 6: Koordinate i standardne devijacije za TP02 (Doy:198-199-200)

\begin{tabular}{rcccccc}
\hline TP02 - Doy: 198 & $X(\mathrm{~m})$ & $Y(\mathrm{~m})$ & $Z(\mathrm{~m})$ & $S_{X}(\mathrm{~m})$ & $S_{Y}(\mathrm{~m})$ & $S_{Z}(\mathrm{~m})$ \\
\hline TopconTools v8.2 & 4219283.5020 & 2328139.8750 & 4164446.0520 & 0.0049 & 0.0044 & 0.0110 \\
AUSPOS & 4219284.3150 & 2328139.7620 & 4164446.3010 & 0.2650 & 0.1280 & 0.3740 \\
OPUS & 4219284.4670 & 2328139.5760 & 4164446.2660 & 0.2710 & 0.4020 & 0.0410 \\
CSRS-PPP & 4219283.9160 & 2328139.8280 & 4164446.1980 & 0.0690 & 0.0220 & 0.0220 \\
APPS & 4219284.3206 & 2328139.8274 & 4164446.3074 & 0.0200 & 0.0156 & 0.0158 \\
GAPS & 4219284.0621 & 2328139.6966 & 4164446.1584 & 0.0105 & 0.0038 & 0.0049 \\
\hline TP02 - Doy:199 & $X(\mathrm{~m})$ & $Y(\mathrm{~m})$ & $Z(\mathrm{~m})$ & $S_{X}(\mathrm{~m})$ & $S_{Y}(\mathrm{~m})$ & $S_{Z}(\mathrm{~m})$ \\
\hline TopconTools v8.2 & 4219283.5410 & 2328139.8720 & 4164446.0260 & 0.0093 & 0.0083 & 0.0230 \\
AUSPOS & 4219283.4590 & 2328139.9670 & 4164446.0870 & 0.0270 & 0.0390 & 0.1430 \\
OPUS & 4219283.6920 & 2328139.5500 & 41644445.9810 & 0.5090 & 0.3390 & 0.4440 \\
CSRS-PPP & 4219283.6870 & 2328140.1220 & 4164446.2350 & 0.0230 & 0.0420 & 0.0250 \\
APPS & 4219283.6085 & 2328139.7232 & 4164445.9679 & 0.0143 & 0.0133 & 0.0127 \\
GAPS & 4219283.6394 & 2328139.7767 & 4164446.0291 & 0.0038 & 0.0054 & 0.0034 \\
TP02 - Doy:200 & $X(\mathrm{~m})$ & $Y(\mathrm{~m})$ & $Z Z(\mathrm{~m})$ & $S_{X}(\mathrm{~m})$ & $S_{Y}(\mathrm{~m})$ & $S_{Z}(\mathrm{~m})$ \\
\hline TopconTools v8.2 & 4219283.5200 & 2328139.8560 & 4164446.0580 & 0.0079 & 0.0063 & 0.0160 \\
AUSPOS & 4219283.4840 & 2328139.9790 & 4164446.1420 & 0.1850 & 0.0350 & 0.1590 \\
OPUS & 4219283.4430 & 2328139.8760 & 4164446.0400 & 0.1310 & 0.1330 & 0.0770 \\
CSRS-PPP & 4219283.6940 & 2328140.1830 & 4164446.3560 & 0.0190 & 0.0470 & 0.0340 \\
APPS & 4219283.5500 & 2328139.9281 & 4164446.1100 & 0.0279 & 0.0304 & 0.0264 \\
GAPS & 4219283.4959 & 2328139.8049 & 4164446.0040 & 0.0035 & 0.0050 & 0.0035
\end{tabular}

To compare the accuracies of web-based online services using relative and PPP solutions, the coordinates estimated by TopconTools v8.2 commercial software are taken as reference. The coordinate differences of each web based online services subtracted from reference coordinates and their standard deviations have been computed by Eq. 3 and Eq.4 for TP01 and TP02.

$$
\begin{gathered}
\mathbf{d}=\mathbf{X}_{\text {WEB SERVICE }}-\mathbf{X}_{\text {REFERENCE }} \\
S_{d}=\sqrt{S_{\text {webservice }}^{2}+S_{\text {xreference }}^{2}}
\end{gathered}
$$

Here, $\mathbf{d}$ is the difference vector; $\mathbf{X}$ is the Cartesian coordinates $(\mathrm{X}, \mathrm{Y}, \mathrm{Z})$ of points, and $\mathrm{S}_{\mathrm{d}}$ is the standard deviation. The 

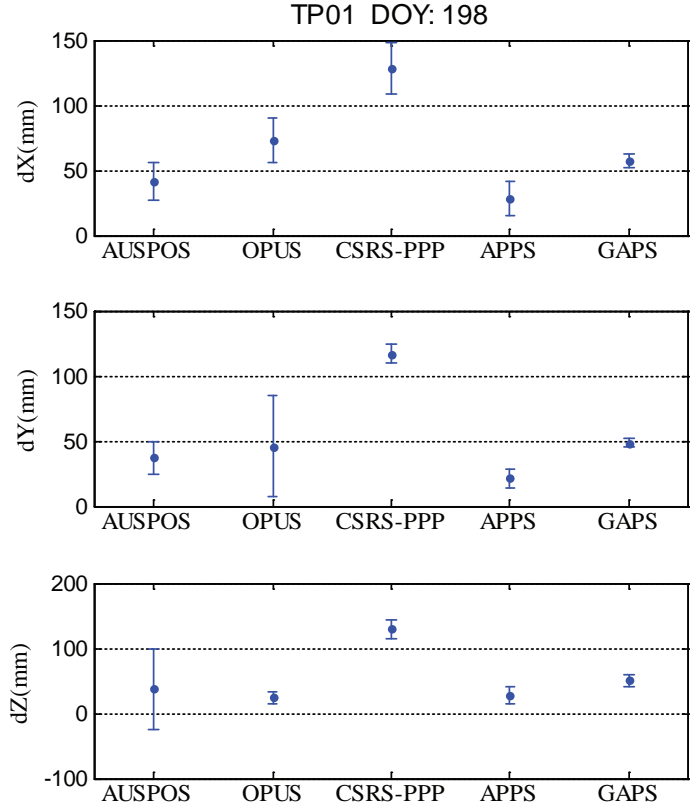

Figure 4: Coordinate differences and standard deviations of TP01 (Doy:198) for X,Y,Z

Slika 4: Razlike koordinata i standardne devijacije za TP01 (Doy:198) za $\mathrm{X}, \mathrm{Y}, \mathrm{Z}$

coordinate differences and standard deviations of TP01 computed by above equations are represented graphically as shown in Figure 4-5-6 for Doy: 198, 199 and 200, respectively. TP01 is located around the border of forest environment and satellite visibility is better than the other test point. When the results have been investigated for TP01, it is seen that the lowest accuracy have been provided by CSRS-PPP service.
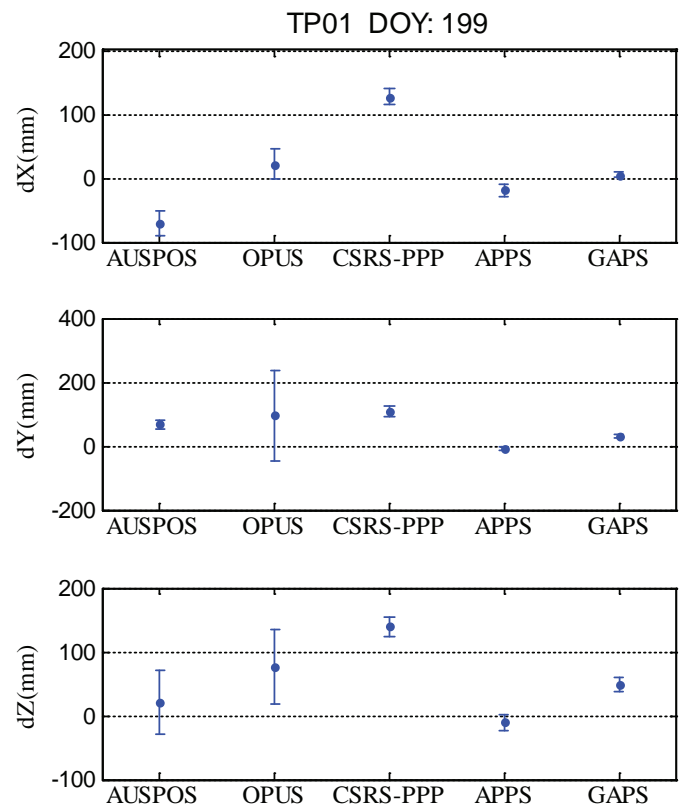

Figure 5: Coordinate differences and standard deviations of TP01 (Doy:199) for X,Y,Z

Slika 5: Razlike koordinata i standardne devijacije za TP01 (Doy:199) za $X, Y Z$
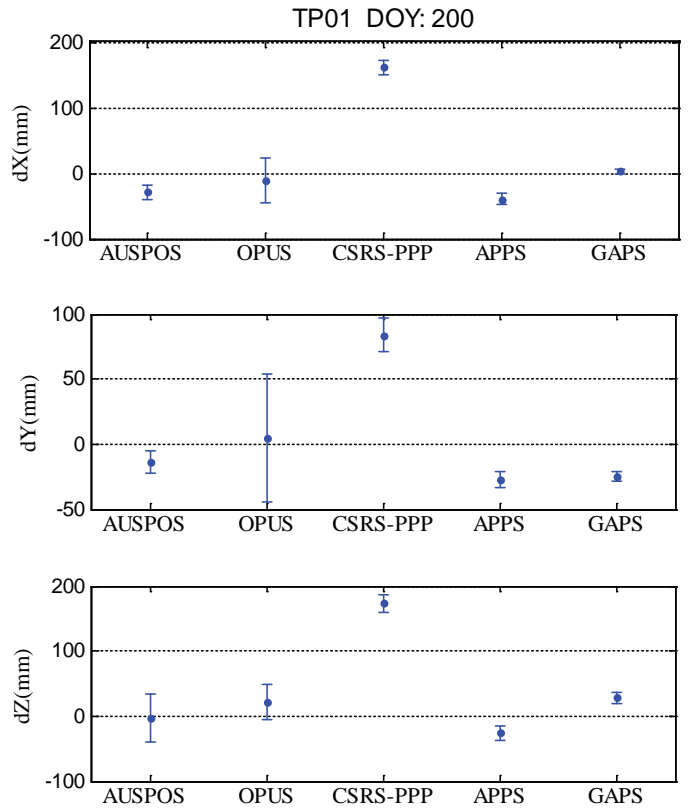

Figure 6: Coordinate differences and standard deviations of TP01 (Doy:200) for $X, Y, Z$

Slika 6: Razlike koordinata i standardne devijacije za TP01 (Doy:200) za $\mathrm{X}, \mathrm{Y}, \mathrm{Z}$

When the other services have been investigated, it can be concluded that AUSPOS and OPUS services using relative solution and APPS and GAPS services using PPP solution have given relatively similar solutions that are close to each other. While the coordinate differences have taken into consideration, the smallest differences have been estimated by APPS service. In addition to this, the lowest standard devi-
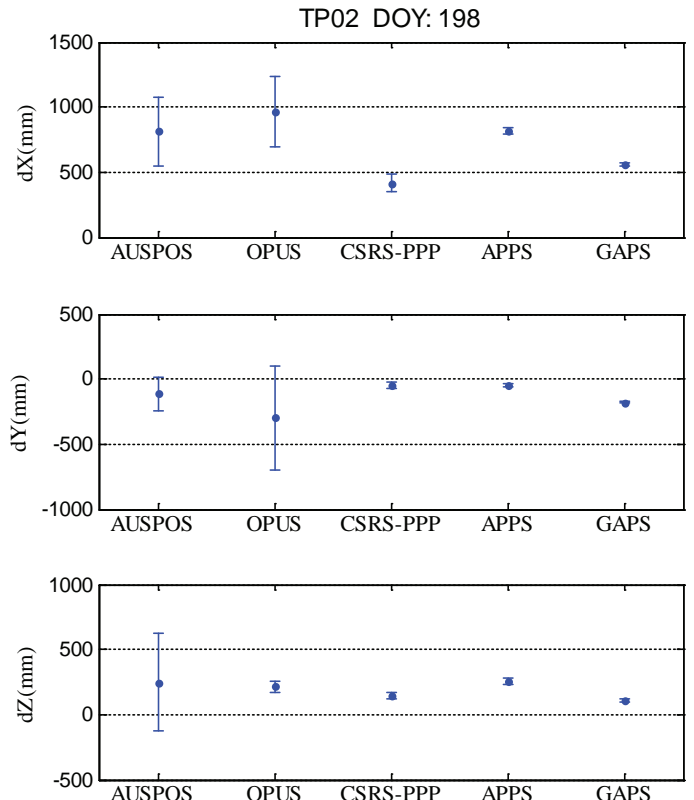

Figure 7: Coordinate differences and standard deviations of TP02 (Doy:198) for X,Y,Z

Slika 7: Razlike koordinata i standardne devijacije za TP02 (Doy:198) za $X, Y, Z$ 

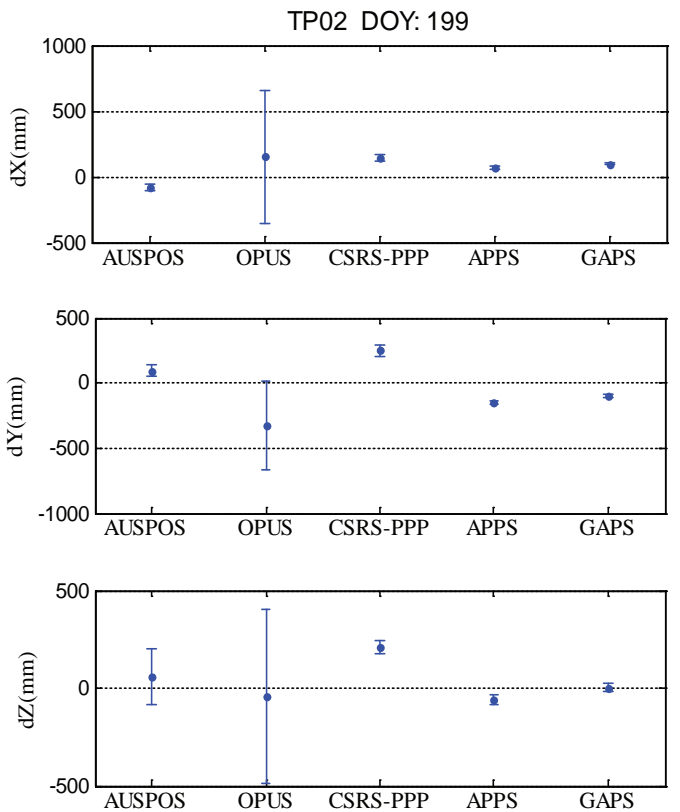

Figure 8: Coordinate differences and standard deviations of TP02 (Doy:199) for $X, Y, Z$

Slika 8: Razlike koordinata i standardne devijacije za TP02 (Doy:199) za $X, Y, Z$

ations have been estimated by GAPS service solutions. When comparing relative solutions for TP01, it is found that AUSPOS service gives more accurate solutions than OPUS service. Moreover, the standard deviations obtained from OPUS service are bigger than AUSPOS service solutions.

The coordinate differences and standard deviations of TP02 computed by Eq. 3 and Eq. 4 are represented graphically as shown in Figure 7-8-9 for Doy: 198, 199 and 200, respectively. TP02 is located under the forest are where the satellite visibility is problematic. In this condition, it is seen that web based online services using PPP solution give better accuracy than the services using relative technique. Having small differences on the results, it can be also concluded that GAPS service gives more reliable solutions for TP02 with respect to standard deviations as well. Also with respect to the standard deviations, standard deviations estimated from relative technique are bigger than estimated from services using the PPP solution. This is a significant factor in terms of accuracy of the services. The reason of estimating more reliable solutions from the services using PPP technique is that they are able to model most of the error sources that can be occurred during the observation by considering more parameters. Modeling the errors as listed on Table 3 is performed automatically with the related services. However, some of the services present alternatives of error models that give preferences to the users. Advanced mode of GAPS service can be given as an example of this situation.
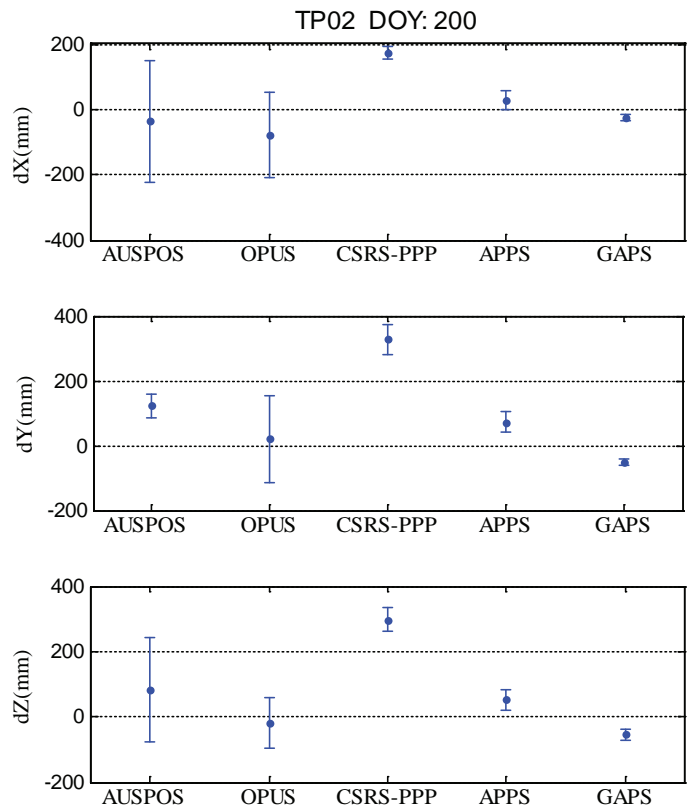

Figure 9: Coordinate differences and standard deviations of TP02 (Doy:200) for $X, Y, Z$

Slika 9: Razlike koordinata i standardne devijacije za TP02 (Doy:200) za $X, Y, Z$

While comparing the results for TP01 and TP02, which have different locational characteristic, the effect of satellite visibility on positional accuracy stand out. All solutions provided by services for TP01 is more reliable than TP02 solutions and the positional accuracies are better as well.

At the above figures, differences of each coordinates components have been represented separately. Moreover, in this study, to investigate the accuracy and reliability of these services, 3D positioning differences are computed from Eq. 5 . Standard deviations of the positional error are calculated by Gaussian error propagation law.

Naesset and Gjevestad (2008) have collected 2 hours static GPS data in the forest environment and post-processed the data with PPP technique. They have used IGS satellite orbit and clock products in the evaluation process. They have post-processed the data with TerraPos software and from the PPP solution for 2 hours observations; they have provided the mean positional accuracy ranging from $0.270 \mathrm{~m}$ to $0.880 \mathrm{~m}$ (Naesset and Gjevestad, 2008). While the observation duration is increased to 3 hours, it can be concluded that the results with PPP solution that have been obtained by 2 hours observations, can be more reliable.

Brach and Zasada (2014) follow a different way to provide high accuracy under the forested area. They research the effect of the changing heights of GPS receiver as $5 \mathrm{~m}, 10 \mathrm{~m}$ and $15 \mathrm{~m}$ by real-time measurements. In this study, they

$$
d_{F}=\sqrt{\left(\mathrm{X}_{\text {WEB SERVICE }}-\mathrm{X}_{\text {REFERENCE }}\right)^{2}+\left(\mathrm{Y}_{\text {WEB SERVICE }}-\mathrm{Y}_{\text {REFERENCE }}\right)^{2}+\left(\mathrm{Z}_{\text {WEB SERVICE }}-\mathrm{Z}_{\text {REFERENCE }}\right)^{2}} .
$$



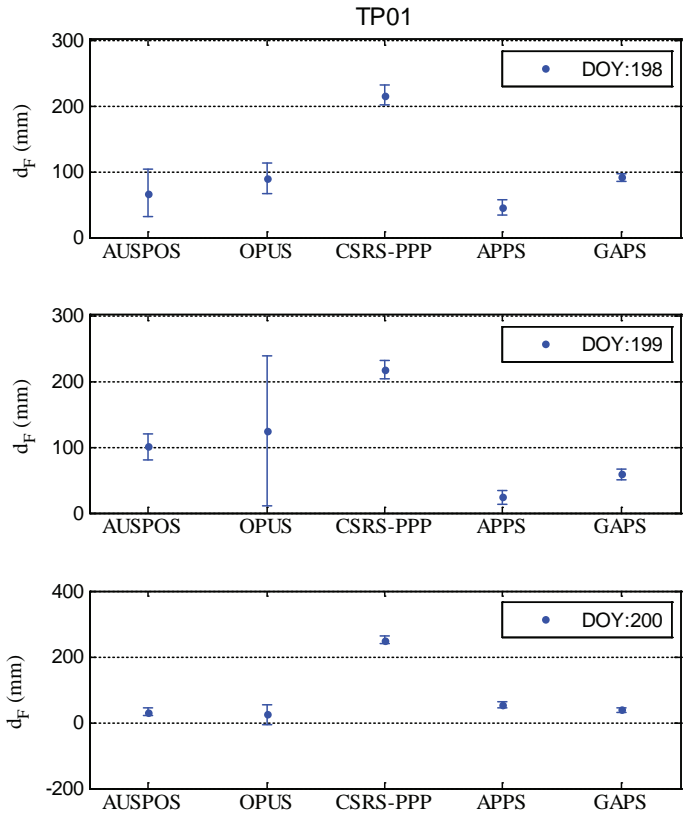

Figure 10: 3D positioning differences and standard deviations for TP01 Slika 10: Razlike u 3D određivanju položaja i standardne devijacije za TP01

state that using higher masts brings an increase in operating costs as well as technical difficulties, e.g. the weight of the mast, problems with electrical power, the mast tilt, etc. and shows insignificant improvement in terms of accuracy, especially in the leaf-off season (Brach and Zasada, 2014).

Considering the graphics of 3D positioning differences for TP01 and TP02, it is seen that smaller errors have been estimated for TP01 point, where satellite visibility is better. Analyses for TP01 show that APPS service generally gives better solutions. For TP02, APPS and GAPS services give close solutions to each other.

\section{CONCLUSION} ZAKLJUČAK

Traditionally, static GPS observations are collected and relative technique are implemented for high accurate GPS point positioning applications. To achieve this, high cost geodetic grade GPS receivers and post-processing software are used. Accuracies estimated from relative technique basically depend on observation duration and baseline length between points. Data collected are post-processed either scientific or commercial software with respect to aim of the study and baseline length between points. The accuracy of point positioning estimated is frequently found in $\mathrm{mm}$ to $\mathrm{cm}$ levels.

For high precise and Real-Time differential positioning, GPS-RTK techniques have been preferred. Today, either single-base RTK (classic-RTK) or network-RTK technique has been used for this purpose to achieve cm level positioning accuracies.
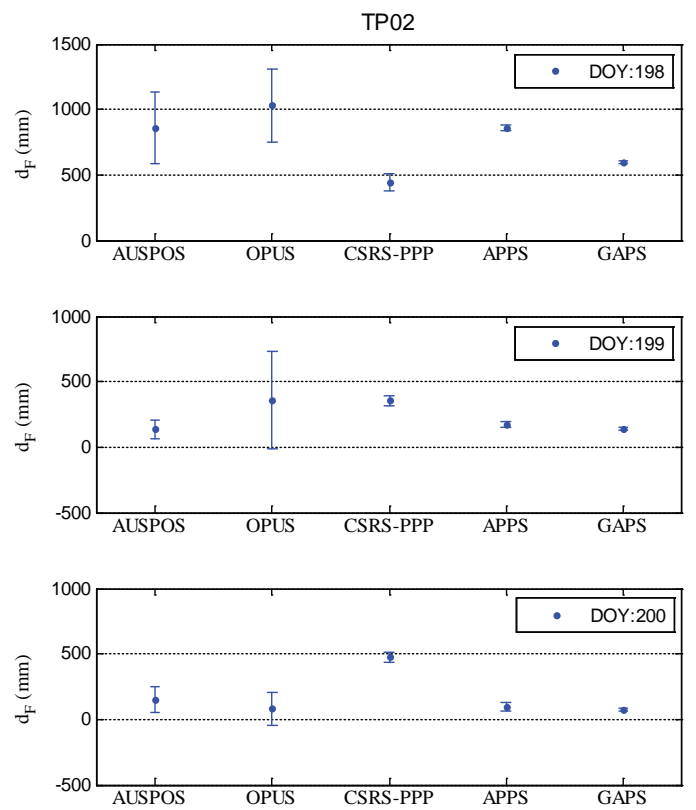

Figure 11: 3D positioning differences and standard deviations for TP02 Slika 11: Razlike u 3D određivanju položaja i standardne devijacije za TP02

Recently, PPP technique, which is an absolute positioning technique, has been used widely as an alternative to the above mentioned techniques. This technique, by having the ability of using the GPS pseudorange and carrier phase observations together, provides high accurate solutions with respect to observation duration. However, in this technique, minimum 20 minutes or more observation duration is required for GPS carrier phase integer ambiguity (float) resolution. As well as increase of the use PPP technique, the web based online positioning services, being free of charge, implemented this technique are gradually increasing. These services also present a significant alternative to the high cost scientific and commercial software. Developments of PPP technique and web based online services provide several advantages to the users with respect to time, cost, accuracy and labor.

For the applications that conducted for protecting and assessment of the natural resources of forest environment, this services are important alternatives while considering these advantages. In this study that conducted for this purpose, 3-day repeated static GPS observations with 3-hours observation duration per day have been collected. The observations have been processed by commercial software and web based online services and results have been compared. In all web based services except APPS, IGS final ephemerides products have been used. In APPS service, final ephemerides products provided by NASA JPL have been used. The results obtained by services using PPP technique show that the most reliable solutions in terms of 3D positioning differences have been provided by APPS and GAPS services.

Considering 3D positioning differences, the positional accuracies for all services implemented both relative and 
PPP solutions are range from $0.024 \mathrm{~m}$ to $0.251 \mathrm{~m}$ for TP01 and range from $00.078 \mathrm{~m}$ to $1.033 \mathrm{~m}$ for TP02.

When the results have been examined for AUSPOS and OPUS services using relative technique, it is found that the positional accuracy for $3 \mathrm{D}$ positioning differences is range from $0.024 \mathrm{~m}$ to $0.124 \mathrm{~m}$ for TP01 and from $0.082 \mathrm{~m}$ to $1.033 \mathrm{~m}$ for TP02.

In addition to this, when the results have been considered for CSRS-PPP, APPS and GAPS services, which are used PPP solution, it is found that the positional accuracy for $3 \mathrm{D}$ positioning differences is range from $0.024 \mathrm{~m}$ to $0.251 \mathrm{~m}$ for TP01 and from $0.078 \mathrm{~m}$ to $0.859 \mathrm{~m}$ for TP02.

It can be concluded that PPP technique and web based online services provide high performance for the applications implemented in the forest environment to achieve precise point positions with 3-hours or more durations of static GPS data observations. With this aspect, PPP technique and web based online services using this technique have become significant alternatives to the user.

\section{ACKNOWLEDGEMENTS}

\section{ZAHVALE}

The author would like to thank to International GNSS Service (IGS) for providing GPS data and products, to Istanbul Water and Sewerage Administration (ISKI), to Geoscience Australia, USA National Geodetic Survey, Natural Resources Canada, University of New Brunswick and NASA's Jet Propulsion Laboratory for providing web based online services.

\section{REFERENCES}

\section{LITERATURA}

- Abd-Elazeem, M., Farah, A. and Farrag, F.A., 2011: Assessment study of using online (CSRS) GPS-PPP Service for mapping applications in Egypt, Journal of Geodetic Science, 1(3):233-239.

- Alkan, R.M., Ocalan, T., 2013: Usability of the GPS Precise Point Positioning Techniques in Marine Applications, Journal of Navigation, 66(4):579-588.

- Awange, J.L., 2012: Environmental Monitoring using GNSS: Global Navigation Satellite Systems, ISBN: 978-3-540-88255-8 (Print), Springer-Verlag.

- Brach, M., Zasada, M., 2014: The Effect of Mounting Height on GNSS Receiver Positioning Accuracy in Forest Conditions, Croatian Journal of Forest Engineering, 35(2): 245-253

- El-Rabbany, A., 2006: Introduction to GPS: The Global Positioning System, Second Edition, Artech House, p. 159-160.

- Gao, Y. and Shen, X., 2001: Improving Convergence Speed of Carrier Pahase based Precise Point Positioning, Proceedings of ION GPS-2001, The Institute of Navigation, 12-14 September 2001, Salt Lack City.

- Gao, Y. and Shen, X., (2002): A New Method For Carrier-PhaseBased Precise Point Positioning, Navigation: Journal of Institute of Navigation, 49(2):109-116.
- Hoffmann-Wellenhof, B., Litchtenegger H.\&Wasle E., 2008: GNSS - Global Navigation Satellite Systems: GPS, GLONASS, Galileo and More, ISBN: 978-3-211-73012-6 (Print), Vienna: Springer-Verlag.

- Naesset, E. and Gjevestad, J.G., 2008: Performance of GPS precise point positioning under conifer forest canopies, Photogrammetric Engineering and Remote Sensing, 74(5):661-668.

- Ocalan, T. and Tunalioglu, N., 2010: Data communication for real-time positioning and navigation in global navigation satellite systems (GNSS)/continuously operating reference stations (CORS) networks, Scientific Research and Essays, 5(18):26302639.

- Ocalan, T., Erdogan, B. and Tunalioglu, N., 2013: Analysis of Web-Based Online Services for GPS Relative and Precise Point Positioning Techniques, Boletim De Ciencias Geodesicas, 19(2):191-207.

- Ocalan, T., 2015: GPS Precise Point Positioning (GPS-PPP) Technique Solutions in GNSS Networks, PhD Thesis, Yildiz Technical University, Graduate School of Natural and Applied Sciences, Intanbul, Turkey.

- Pirti A., 2005: Using GPS System near The Forest and Quality Control, Survey Review, 38(298):286-298.

- Pirti A., 2008: Accuracy Analysis of GPS Positioning Near the Forest Environment, Croatian Journal of Forest Engineering, 29(2):189-201.

- Pirti, A., Ocalan, T., Tunalioglu, N., Hosbas R. G., 2015: An Alternative Method For Point Positioning In The Forested Areas, Sumarski List, (Accepted)

- Rizos, C., Janssen, V., Roberts, C. ve Grinter, T., 2012: Precise Point Positioning: Is the Era of Differential GNSS Positioning Drawing to an End?, FIG Working Week 2012, 6-10 May 2012, Rome, Italy.

- Tsakiri, M., 2008: GPS Processing Using Online Services. ASCE Journal of Surveying Engineering, 134(4):115-125.

- Zumberge, J.F., Heflin, M. B., Jefferson, D. C., Watkins, M. M. and Webb, F. H., 1997: „Precise Point Positioning for the Efficient and Robust Analysis of GPS Data from Large Networks", Journal of Geophysical Research, 102(B3):5005-5017.

- URL-1: International GNSS Service (IGS) web page, www.igs. org

- URL-2: Australian Online GPS Processing Service (AUSPOS) web page, http://wwwb.ga.gov.au/bin/gps.pl

- URL-3: Online Positioning User Service (OPUS) web page, http://www.ngs.noaa. gov/OPUS/

- URL-4: Canadian Spatial Reference System-Presice Point Positioning (CSRS-PPP) web page, http://webapp.geod.nrcan.gc.ca/ geod/tools-outils/ppp.php

- URL-5: GPS Analysis and Positioning Software (GAPS) web page, http://gaps. gge.unb.ca/

- URL-6: Automatic Precise Positioning Service (APPS) web page, http://apps.gdgps.net/

- URL-7: magicPPP-Precise Point Positioning Solution (magicGNSS) web page, http://magicgnss.gmv.com/ppp/

- URL-8: Trimble CenterPoint RTX Post-Processing Service web page, http://www.trimblertx.com/

- URL-9: Istanbul Water and Sewerage Administration (ISKIUKBS) CORS web page, http://ukbs.iski.gov.tr/ 


\section{Sažetak}

Kako je Globalni položajni sustav (GPS) rutinski proveden u mnogim tehnički projektima, također je učinkovito primijenjen u procjeni i zaštiti šumskih i prirodnih izvora. Ovisno o preferiranoj metodi snimanja GPS-om u primjeni na šumskim područjima, mogu se postići različite razine preciznog određivanja položaja. Tradicionalno, u mnogim slučajevima preciznog određivanja položaja, koristilo se relativno statično određivanje položaja. Dobiveni podaci analizirani su skupim znanstvenim i komercijalnim softverom, za koji je potrebno dobro poznavanje postupaka obrade podataka. Međutim, tijekom posljednjih godina internetske usluge koje koriste tehniku Preciznog određivanja položaja (PPP), razvijene kao poseban tip relativnog određivanja položaja, a omogućuju laku obradu i analizu statičnih podataka, postale su značajna alternativa kod korisnika. Ovakav razvoj snimanja na temelju GPS-a, koji je značajno doprinijeo studijama primijenjenima na šumska područja, u smislu štednje vremena, troškova, preciznosti i radne snage, omiljen je u mnogim tehničkim pogonima. U ovom radu cilj je istražiti svojstva Preciznog određivanja položaja (PPP) GPS-om i internetskih usluga u pozicioniranju aplikacija koje se primjenjuju posebno na šumska područja. U tu svrhu postavljene su dvije testne stanice na različitim lokacijama na šumskom području u Kampusu Davutpasa, Tehničko sveučilište Yildiz, u Istanbulu, te su stanice opetovano promatrane statičnim snimanjem GPS-om u periodu od 3 dana, s trajanjem promatranja 3 sata dnevno. Promatranja su obrađena pomoću komercijalnog softvera, kao što je TopconTools v8.2, koji koristi GPS astronomske tablice, te također pomoću internetskih usluga kao što su OPUS, AUSPOS, CSRS-PPP, GAPS i APPS.

Kao rezultat, nakon ispitivanja razlika u 3D određivanju položaja, uočava se da je točnost u određivanju položaja u rasponu od 0,024 m do 0,251 m za TP01, te od 0,078 m do 1,033 m za TP02 u odnosu na relativno određivanje i PPP određivanje položaja, koje koriste internetski servisi. Kada su rezultati ispitani za usluge CSRS-PPP, APPS i GAPS, koje koriste PPP rješenja, uočeno je da točnost u određivanju položaja za 3D pozicioniranje varira od 0,024 $\mathrm{m}$ do $0,251 \mathrm{~m}$ za TP01 te od 0,078 $\mathrm{m}$ do 0,859 $\mathrm{m}$ ta TP02.

Rezultati pokazuju da kako se sakupljaju statični GPS podatci u trajanju od 3 sata i više, PPP tehnika i internetske usluge koje koriste aplikacije preciznog određivanja položaja u šumskim područjima pružaju učinkovita rješenja korisnicima, te istovremeno smanjuju troškove ispitivanja u smislu opreme i softvera.

KLJUČNE RIJEČI: GPS, PPP, internetske usluge, šumska područja, točnost određivanja položaja 